\title{
Therapeutic potential of products derived from mesenchymal stem/stromal cells in pulmonary disease
}

\author{
Arezoo Mohammadipoor ${ }^{1,2^{*}}$, Ben Antebi ${ }^{1}$, Andriy I. Batchinsky ${ }^{1,3}$ and Leopoldo C. Cancio ${ }^{1}$
}

\begin{abstract}
Multipotent mesenchymal stem/stromal cells (MSCs) possess robust self-renewal characteristics and the ability to differentiate into tissue-specific cells. Their therapeutic potential appears promising as evident from their efficacy in several animal models of pulmonary disorders as well as early-phase clinical trials of acute respiratory distress syndrome (ARDS) and chronic obstructive pulmonary disease (COPD). Such therapeutic efficacy might be attributed to MSC-derived products (the "secretome"), namely conditioned media (CM) and extracellular vesicles (EVs), which have been shown to play pivotal roles in the regenerative function of MSCs. Importantly, the EVs secreted by MSCS can transfer a variety of bioactive factors to modulate the function of recipient cells via various mechanisms, including ligand-receptor interactions, direct membrane fusion, endocytosis, or phagocytosis.

Herein, we review the current state-of-the-science of MSC-derived CM and EVs as potential therapeutic agents in lung diseases. We suggest that the MSC-derived secretome might be an appropriate therapeutic agent for treating aggressive pulmonary disorders because of biological and logistical advantages over live cell therapy. Nonetheless, further studies are warranted to elucidate the safety and efficacy of these components in combating pulmonary diseases.
\end{abstract}

Keywords: Mesenchymal stem cells, Extracellular vesicles, Conditioned media, Lung disease, Acute respiratory distress syndrome, Acute lung injury, Chronic obstructive pulmonary disease, Pulmonary fibrosis, Bronchopulmonary dysplasia

\section{Background}

The increasingly high rates of morbidity and mortality due to acute and chronic lung diseases have emerged as one of the major public health issues globally. Pulmonary diseases are mainly caused by trauma, air pollution, smoking, and various pathogens and exert a devastating effect on quality of life [1]. Acute respiratory distress syndrome (ARDS), recognized as the most severe form of acute lung injury (ALI), is a life-threatening condition featuring acute hypoxemic respiratory failure, bilateral consolidation on chest radiograph, and absence of left atrial hypertension [2,3]. ARDS most commonly occurs due to sepsis, smoke inhalation injury, near-drowning, severe pneumonia, or pulmonary contusion [3-6]. Mechanistic studies reveal that dysregulated inflammatory/immune

\footnotetext{
*Correspondence: arezoo.mohammadipoor.ctr@mail.mil;

Arezoo.mohammadipoor.ctr@mail.mil

${ }^{1}$ Multi-Organ Support Technology (MOST) Task Area, US Army Institute of Surgical Research, Fort Sam Houston, TX, USA

${ }^{2}$ Oak Ridge Institute for Science and Education, Oak Ridge, TN, USA

Full list of author information is available at the end of the article
}

responses, uncontrolled activation of coagulation pathways, and increased permeability of alveolar endothelial/epithelial barrier play pivotal roles in the pathogenesis of ARDS [3]. ARDS continues to be associated with a mortality rate of $30 \%$ to $40 \%$ despite advances in modern supportive care [2, 4, 7-9].

Among many destructive chronic lung diseases, such as idiopathic pulmonary fibrosis (IPF) and pulmonary hypertension, chronic obstructive pulmonary disease (COPD) is thought to be one of the leading causes of death worldwide. Approximately $20 \%$ of COPD patients present with emphysema, which is characterized by destruction of terminal bronchioles and alveolar walls causing overdistension of air spaces due to air trapping. Despite advances in the symptomatic treatment of emphysema, a cure remains obscure [1].

Stem-cell-based therapy is an attractive approach for treating both acute and chronic lung diseases, such as ARDS and COPD, mainly because the cells can simultaneously target multiple pathological processes to 
protect lung function. Among the various types of stem cells, the therapeutic potential of mesenchymal stem/stromal cells (MSCs) has been extensively demonstrated in several animal models of pulmonary disorders [10-15], and is now being evaluated in phase II clinical trials for ARDS [16]. It is well established that MSCs impart their therapeutic effect via secretion of bioactive products, namely the secretome $[17,18]$. Although not fully defined, the MSC secretome is comprised of an extended array of bioactive molecules that include cytokines, chemokines, growth factors, angiogenic factors, and extracellular vesicles (EVs), thus potentially contributing to the therapeutic benefits of the cells as evident from preclinical studies [19-23]. MSC secretome is readily available in the conditioned media (CM) of MSC cultures (MSC-CM) and, subsequently, MSC-derived EVs are isolated from the CM. The major advantage of MSC-derived secretome therapy over live-cell transplantation approach can be attributed to the inherent risks associated with live-cell transplants. Consequently, the MSC secretome is emerging as a viable option to replace the cells for the treatment of several lung disorders.

In this review, we describe the characteristics of MSC-CM and MSC-EVs as well as the methods of their isolation. Next, we summarize the current state-of-the-science relating to their therapeutic potential for various lung diseases. Finally, we will discuss the advantages and limitations of these products in clinical settings.

\section{MSC-derived products: Light at the end of the tunnel} Mesenchymal stem/stromal cells at a glance

In 1968, Friedenstein and colleagues first discovered MSCs as a component of bone-marrow stromal tissue [24]. Subsequently, MSCs have been isolated from various tissues, such as adipose tissue, umbilical cord (UC) blood/tissue, placental tissue, and exfoliated deciduous teeth [25-29]. Since no unique surface marker(s) can exclusively identify these cells, in 2006, the Mesenchymal and Tissue Stem Cell Committee of the International Society for Cellular Therapy proposed the following criteria as minimal criteria to be satisfied for defining human MSCs. First, the cells must be plastic-adherent when maintained in standard culture conditions. Second, MSCs must express surface antigens such as CD105, CD73, and CD90 but should lack the expression of the following hematopoietic antigens: CD45, CD34, CD14 or CD11b, CD79a or CD19, and human leukocyte antigen (HLA)-DR. Third, MSCs must be capable of differentiating into osteoblasts, adipocytes, and chondroblasts in vitro [30]. That MSCs are easy to isolate and expand in culture is a major advantage from a logistical/feasibility standpoint. More importantly, MSCs have evolved as one of the mainstream cell-based therapeutic tools for regenerative medicine because of their inherent low immunogenicity and limited risk of tumorigenicity $[29,31,32]$.

The initial motive for exploring their therapeutic benefits stemmed from the capability of MSCs to repair injured tissues by engrafting and replacing damaged cells through differentiation [29]. An array of other observations, however, suggests that MSCs could repair injured tissues and improve function without significant engraftment or differentiation. In fact, emerging evidence suggests that the therapeutic benefits of MSCs are derived from their secretome, and the subsequent paracrine action [29, 31-34].

\section{MSC Secretome}

The MSC-derived secretome is released into $\mathrm{CM}$ in vitro [19-22, 32, 35-41]. MSCs respond to environmental changes and stress signals from injured tissues by secreting a myriad of soluble factors (Table 1); for instance, early reports by Prockop and others showed that in response to hypoxia, MSCs correlatively increase the production of several angiogenic and anti-apoptotic factors, such as interleukin-6 (IL-6), vascular endothelial growth factor (VEGF), monocyte chemotactic protein (MCP-1), also known as chemokine [C-C motif] ligand 2 (CCL2)), and stanniocalcin-1 (STC-1) $[36,37]$. In line with these findings, further studies revealed that the stimulation of MSCs with different insults and inflammatory cytokines, including lipopolysaccharide (LPS), tumor necrosis factor alpha (TNF- $\alpha$ ), IL- $1 \beta$, interferon gamma (IFN- $\gamma$ ), and serum from ARDS patients can induce the secretion of a variety of anti-inflammatory mediators, such as TNF-stimulating gene 6 protein (TSG-6), prostaglandin E2 (PGE2), indoleamine 2,3-dioxygenase (IDO), IL-10, and IL-1 receptor antagonist (IL-1ra) [39, 42-44].

Recent efforts have focused on the paracrine effects of MSCs both in vitro and in vivo [45-52]. MSC bioactive factors have been reported to mediate several known functions of MSCs, including the modulation of immune/inflammatory responses, reduction of oxidative stress, fibrosis, and apoptosis. They also promote angiogenesis, bacterial clearance, and regeneration. In addition to their soluble factors, MSCs also secrete different types of EVs contributing to the overall therapeutic response [19-23, 40, 41].

Structurally, EVs are nano- to micro-sized particles surrounded by a phospholipid bilayer. Most eukaryotes and prokaryotes have been shown to secrete a heterogeneous population of EVs. The presence of these vesicles can be detected in physiological fluids, such as plasma, urine, cerebrospinal fluid, milk as well as in the supernatant of cell cultures in vitro [53-55]. Of note, EVs were considered as cell debris [53, 55-57] till 1996 when Raposo et al. [58] presented evidence of their biological function. They demonstrated that EVs secreted by B 
Table 1 Bioactive factors secreted by MSCs directly in CM or via EVs

\begin{tabular}{|c|c|c|c|c|c|c|}
\hline Angiogenesis & Anti-apoptosis & Anti-fibrosis & Anti-oxidation & Chemo-attraction & Immuno- modulation & Proliferation \\
\hline Ang1 & FGF & Ang-1 & $\mathrm{HO}-1$ & CCLs & $\mathrm{HO}-1$ & FGF \\
\hline FGF & GM-CSF & FGF & $I L-1 \beta$ & CXCLS & IDO & HGF \\
\hline HGF & HGF & HGF & STC-1 & G-CSF & IL-1ra & IGF-1 \\
\hline IGF-1 & IGF-1 & KGF & & LIF & IL-6 & KGF \\
\hline IL-6 & IL-6 & MMPs & & M-CSF & $\| \mathrm{L}-10$ & PDGF \\
\hline MCP-1 & STC-1 & TIMP-1 & & $\mathrm{MCP}-1$ & LIF & VEGF \\
\hline PDGF & & & & SDF-1 & PGE2 & \\
\hline \multirow[t]{3}{*}{ VEGF } & & & & & STC-1 & \\
\hline & & & & & TGF- $\beta$ & \\
\hline & & & & & TSG-6 & \\
\hline
\end{tabular}

Ang-1 - angiopoietin 1, CCL - chemokine ligand, CXCL - chemokine (C-X-C motif) ligand, FGF - fibroblast growth factor, GM-CSF - granulocyte monocyte colony stimulating factor, HGF - hepatocyte growth factor, HO-1 - hemeoxygenase 1, IDO - indoleamine 2,3-dioxygenase, IGF-1 - insulin like growth factor 1, IL interleukin, IL-1 ra - IL-1 receptor antagonist, KGF - keratinocyte growth factor, LIF - leukemia inhibitory factor, LL-37 - human cathelicidin, MMP -

metalloproteinase, MCP-1 - monocyte chemoattractant protein 1, PDGF - platelet derived growth factor, PGE2 - prostaglandin E2, SDF-1 - stem cell-derived factor 1, STC-1 - stanniocalcin 1, TIMP-1 - tissue inhibitor of metalloproteinase 1, TGF- $\beta$ - transforming growth factor beta, TSG-6 - tumor necrosis factor-stimulated gene 6, VEGF - vascular endothelial growth factor

lymphocytes can induce antigen-specific T lymphocyte responses in vitro. The pioneering observation by these authors prompted elaborate studies to establish the role of EVs as critical mediators in cell-to-cell communication $[53,57,59-61]$. Cumulative studies in the field reveal that upon their release into the extracellular milieu, EVs can interact with recipient cells by ligand-receptor interaction or by internalization via endocytosis, phagocytosis, and direct membrane fusion (Fig. 1). Targeted delivery of EVs to specific cells/tissues is facilitated by several types of membrane molecules that are embedded in the lipid bilayers. Interestingly, several studies reported the ability of EVs to regulate a variety of biological responses in recipient cells via transfer of an array of bioactive factors that include proteins, lipids, nucleic acids (mRNA, microRNA, transfer RNA, and double-stranded DNAs), as well as cellular organelles $[41,53,57]$. At present, based on their cellular origin, secretory mechanism, size, and surface markers, EVs are classified into 3 main categories 1) exosomes; 2) microvesicles; and 3) apoptotic bodies.

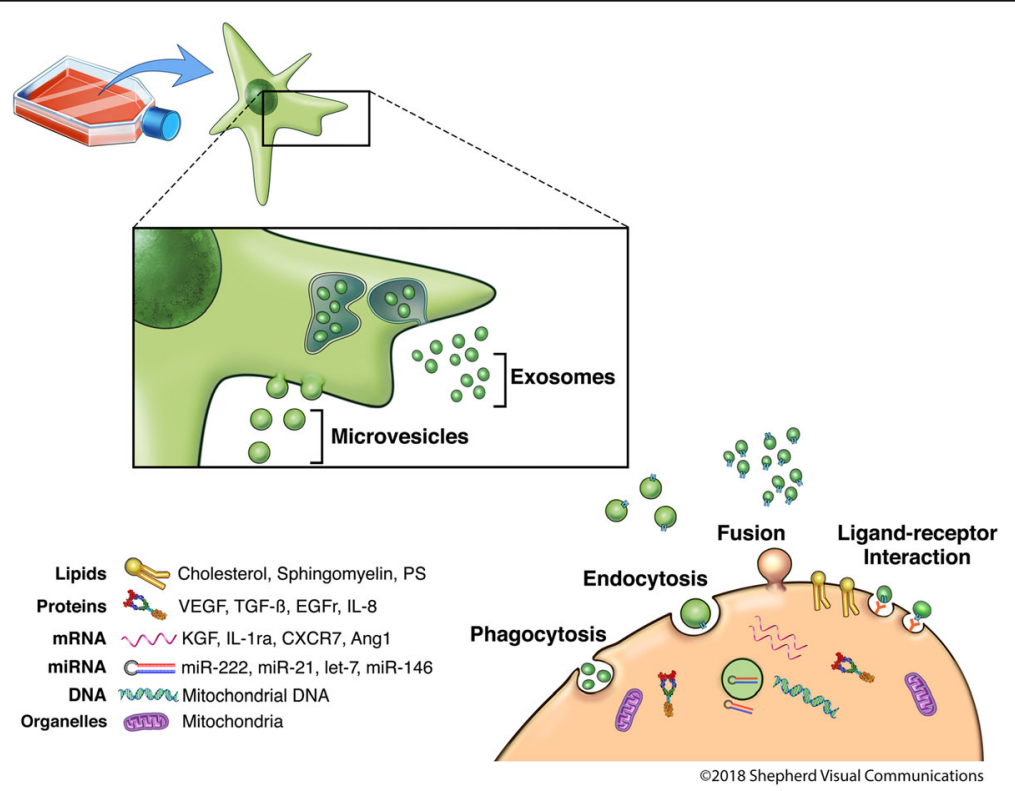

Fig. 1 Extracellular vesicles secreted by mesenchymal stem cells transfer their cargo to the recipient cells. In culture mesenchymal stem cells secrete exosomes and microvesicles that can transfer variety of bioactive factors to the recipient cells via ligand-receptor interaction, direct membrane fusion, endocytosis, or phagocytosis. Ang1-angiopoietin 1, CXCR7 - chemokine (C-X-C motif) receptor 7, EGFr - epidermal growth factor receptor, IL-8 - interleukin 8, IL-1 ra - IL-1 receptor antagonist, KGF - keratinocyte growth factor, mRNA - messenger RNA, miRNA - micro RNA, PS - phosphatidylserine, TGF- $\beta$ - transforming growth factor beta, VEGF - vascular endothelial growth factor 
Exosomes are formed by the inward budding of multi-vesicular bodies (MVBs), size $\sim 40-100 \mathrm{~nm}$, and rich in CD63, CD9, CD81, and tumor susceptibility gene 101 (Tsg 101). These vesicles are also enriched in annexins, ALG-2-interacting protein X (Alix), clathrin, heat shock proteins, and low amounts of phosphatidylserine (PS). Cytoskeleton activation is required for their release.

Microvesicles (shedding vesicles) are formed by budding from the plasma membrane, size $\sim 80-1000 \mathrm{~nm}$, and rich in integrins, selectins, and CD40 ligands. Their release is dependent on cytoskeleton activation as well as calcium influx. The lipid bilayer of microvesicles is enriched in cholesterol, sphingomyelin, ceramide, and PS.

Apoptotic bodies are derived from fragmentation of cells undergoing apoptosis, size $\sim 1000-5000 \mathrm{~nm}$, and rich in PS, nuclear fractions, and cellular organelles. While the role of cytoskeleton-associated molecules in the formation and the release of apoptotic bodies has been implicated, the mechanism responsible for relocation of fragmented DNA still remains unclear $[18,53,62,63]$.

It is now established that MSCs secrete all types of EVs [64]. The heterogeneous pool of MSC-EVs has been shown to express both EV- and MSC-specific surface markers, such as CD63, CD9, CD81, integrins, CD29, CD44, CD73, and $\alpha 4$-integrin [23, 65-67]. Similarly, both ubiquitous and MSC-specific proteins and nucleic acids are enveloped in these EVs (Fig. 1). Interestingly, certain proteins and nucleic acids are selectively enriched in EVs compared to their parental cells. For instance, Collino and colleagues [2010] identified that while microvesicles derived from bone marrow MSCs contain their parental cell-specific microRNAs (miR), the expression level of some was significantly higher in microvesicles compared to MSCs (miR-223, miR-451, and miR-564) [68]. It has also been shown that horizontal transfer of functional RNAs and proteins is involved in general cell functions, such as cell development, proliferation, survival, and differentiation, as well as regulation of the immune system [18], angiogenesis [69], and ATP generation [70]. Unequivocally, interest in exploring the therapeutic potential of MSC-EVs has evolved; however, at this stage, further investigation is warranted in regards to the unveiling of the composite profile of the contents of these vesicles and the elucidation of the potential therapeutic efficacy of these components.

\section{Preparation of MSC-CM and MSC-EVs}

MSC-CM is considered the least processed cell-free product from MSCs. Based on the source of MSCs, culture condition, culture duration, and collection method, different quantities of secreted factors may be detected in the CM [50]. Generally, MSCs are cultured in their growth media as monolayers or aggregates. Once cells reach approximately $80 \%$ confluence, serum-containing growth media are replaced with fresh media [36, 47, 49, 50, 71]. In order to decrease contamination of the CM by extrinsic sources, such as fetal bovine serum, serum-free media are commonly used at this step [57]. On the other hand, chemically defined media or EV-depleted serum containing media are suggested to reduce the effect of nutrition starvation on MSCs [72]. As previously mentioned, environmental signals influence the paracrine activity of MSCs; therefore, the cells can be exposed to different stimuli, including hypoxia or pro-inflammatory cytokines to promote the secretion of certain therapeutic molecules in vitro. At the end of the incubation period (commonly 24$48 \mathrm{~h}$ ), the supernatant is collected from the MSC cultures. The cellular component is subsequently removed by density-gradient centrifugation or filtration. At this step, the cell-free product is considered MSC-CM. It is optional to concentrate MSC-CM before in vitro and in vivo applications. Following preparation, the CM can be stored at $-80^{\circ} \mathrm{C}$ or subsequently processed for EV isolation.

There are several approaches to determine the yield of the MSC-CM. One of the most common approaches is based on the number of MSCs from which the CM was derived $[47,71,73-76]$. Other parameters, including total proteins and the concentration of certain soluble bioactive mediators, have also been considered for characterization and dosage determination of MSC-CM [46, 49, 50, 77]. A variety of techniques may be used to isolate and concentrate different fractions (e.g., exosomes or microvesicles) of EVs from CM; these include ultracentrifugation, filtration and chromatography, precipitation, and immuno-affinity [78]. Each method provides different degrees of purity and enrichment; however, none of the available methods can completely separate the different types of EVs from each other or from non-EV fractions (e.g. soluble proteins, cell-free nucleic acids, and membrane fractions). Combinations of two or more methods may be used to improve the purity of certain fractions of EVs. Assessment of isolated EVs is mainly done by determination of concentration and size distributions using different methods, such as nanoparticle tracking analysis (NTA), transmission electron microscopy, and flow cytometry. In addition, the amount of total proteins in EVs is commonly assessed and used to select EV dosage for in vitro and in vivo studies. Similar to CM, the concentration of EVs or their total protein can be normalized to the number of MSCs from which they are derived. The final product can further be concentrated and stored for short periods at $4{ }^{\circ} \mathrm{C}$. For longer storage, EVs can be placed in $\leq-20{ }^{\circ} \mathrm{C}$ without the need of cryopreservatives.

\section{Therapeutic potential of MSC-CM in lung injury}

So far, the ability of MSC-CM to significantly reduce the severity of lung injury, as effectively as MSCs, has been demonstrated in several in vitro and in vivo preclinical animal models (Table 2). To this end, Pati et al. showed 
Table 2 Summary of therapeutic benefits of MSC-CM in preclinical animal models

\begin{tabular}{|c|c|c|c|c|c|}
\hline CM Source & Route & Injury Model & Outcomes & Key Factor & Ref. \\
\hline Mouse BM-MSC & IT & Mouse-ALI/LPS & $\begin{array}{l}\downarrow \text { Neutrophils in BALF } \\
\uparrow \mathrm{M} 2 \text { in BALF }\end{array}$ & IGF-1 & {$[74]$} \\
\hline Human BM-MSC & IV & Rat-Pneumonia/E. coli & $\uparrow$ Survival & $\mathrm{LL}-37$ & [81] \\
\hline Rat BM-MSC & IT & Rat-Lung Injury/l/R & $\begin{array}{l}\downarrow \text { Pro-inflammatory cytokines } \\
\downarrow \text { Neutrophils in BALF } \\
\uparrow \text { M2 \& Treg in BALF }\end{array}$ & & [82] \\
\hline Mouse BMC & IN & Mouse-Asthma/OVA & $\begin{array}{l}\downarrow \text { Airway inflammation } \\
\downarrow \text { Airway hyper-responsiveness } \\
\downarrow \text { Airway smooth muscle thickness } \\
\uparrow \text { IL-10 producing Treg \& macrophages }\end{array}$ & APN & [83] \\
\hline Mouse BM-MSC & IV & Neonatal Mouse-BPD/Hyperoxia & $\begin{array}{l}\downarrow \text { Right ventricular hypertrophy } \\
\downarrow \text { Intrapulmonary arterioles muscularization } \\
\downarrow \text { Inflammatory cells \& cytokines in BALF } \\
\text { Preserve alveoli morphology } \\
\uparrow \text { Number of BASCs }\end{array}$ & $\begin{array}{l}\text { Opn } \\
\text { Csf1 }\end{array}$ & {$[71,84,85$} \\
\hline Hyperoxia Preconditioned Rat BM-MSC & IP & Neonatal Rat- BPD/Hyperoxia & $\begin{array}{l}\downarrow \text { PAH } \\
\downarrow \text { Right ventricular hypertrophy } \\
\downarrow \text { Pulmonary artery medial wall thickness } \\
\text { Improved lung structure }\end{array}$ & STC-1 & [87] \\
\hline Rat BM-MSC & IT & $\begin{array}{l}\text { Rat-Lung Fibrosis/ } \\
\text { Bleomycin }\end{array}$ & $\begin{array}{l}\downarrow \text { Lung fibrosis } \\
\downarrow \text { AEC apoptosis }\end{array}$ & & {$[76]$} \\
\hline Rat BM-MSC & IV & Rat-COPD/ cigarette smoke & $\begin{array}{l}\downarrow \text { Lung emphysema } \\
\downarrow \text { Pulmonary artery medial wall thickness } \\
\uparrow \text { Number of small pulmonary vessels } \\
\text { Protect lung fibroblasts }\end{array}$ & & {$[91,92]$} \\
\hline
\end{tabular}

$\overline{A E C}$ - alveolar epithelial cell, $A L I$ - acute lung injury, $A P N$ - adiponectin, $B A L F$ - bronchoalveolar lavage fluid, $B A S C S$ - bronchoalveolar stem cells, $B M-M S C$ - bone marrow-derived mesenchymal stem cells, BPD - bronchopulmonary dysplasia, COPD - chronic obstructive pulmonary disease, Csf1 - macrophage colony stimulating factor 1 (M-CSF), E. coli - Escherichia coli, IN - intranasal, IP - intraperitoneally, I/R - ischemia reperfusion, IT - intratracheal, IV - intravenous, LPS lipopolysaccharide, M2 - macrophage type 2, Opn - osteopontin, OVA - ovalbumin, PAH - pulmonary artery hypertension, STC-1 - stanniocalcin 1, Treg regulatory $\mathrm{T}$ lymphocyte

that MSC-CM prevented endothelial cell permeability and restored the normal status of membrane adhesion molecules ( $\beta$-catenin and VE-cadherin) in vitro. MSC-CM also reduced the adhesion of leukocytes to endothelial cells, thus suggesting that MSC-CM can moderate the inflammatory response of the injured endothelium by preserving vascular barrier integrity and preventing inflammatory cell binding to endothelial cells [79]. In another in vitro study, Ortiz et al. demonstrated the capability of MSC-CM to reduce the secretion of TNF- $\alpha$ by macrophages. Such anti-inflammatory effect of MSC-CM was suggested to be mediated by IL-1ra [10].

Lee and colleagues investigated alveolar fluid transport using whole human lungs in an ex vivo lung perfusion model. The idea of such experimental studies stemmed from the notion that impaired alveolar fluid clearance is associated with higher mortality in ARDS patients. In this study, the therapeutic benefits of MSCs and MSC-CM were evaluated by the extent of their ability to restore alveolar fluid clearance in ALI. The experimental design consisted of delivery of Escherichia coli (E. coli) endotoxin intra-bronchially to perfused lungs, followed by the administration of MSCs or MSC-CM one hour following induction of injury. Both treatments improved lung endothelial barrier integrity and the rate of alveolar fluid transport. This study also revealed the essential role of keratinocyte growth factor (KGF), a MSC component, in alveolar fluid transport. MSC pretreatment with KGF small-interference RNA (siRNA) decreased the effect of MSC-CM on alveolar fluid clearance. Conversely, this effect was restored by the addition of recombinant KGF protein to the CM [80].

Further studies to elucidate the anti-inflammatory potential of MSC-CM were extended to several small animal models of ALI. In this pursuit, Ionescu et al. showed that intratracheal (IT) administration of MSCs or MSC-CM reduced the total number of infiltrated neutrophils in bronchoalveolar lavage fluid (BALF) in mice with endotoxin-induced ALI. Of note, the administration of fibroblasts or fibroblast-CM did not reproduce the same effect thus demonstrating MSC specificity. Concurrently, the flow-cytometric analysis revealed that MSC and MSC-CM administration increased the percentage of inducible nitric oxide synthase (iNOS)-Ym1 ${ }^{+}$ alveolar macrophages in BALF, resembling the phenotype associated with alternatively activated macrophages (M2). Insulin-like growth factor 1 (IGF-1) was detected in MSC-CM, suggesting its role in polarization of alveolar macrophages to the M2 phenotype and protection of lungs from endotoxin-induced injury [74]. In another 
study, Devaney and colleagues reported that intravenous (IV) and IT administration of MSCs reduced the infiltration of neutrophils, IL-6, and the total amount of protein in BALF in a rat model of $E$. coli-induced pneumonia. MSCs also improved survival and bacterial clearance and preserved lung function. In contrast, MSC-CM improved animal survival without any significant mitigation of the severity of lung injury or inflammation [81]. Experimental evidence on the studies addressing the anti-inflammatory potential of MSC-CM revealed that MSC-CM pretreatment significantly reduced the amount of pro-inflammatory cytokines and the number of infiltrated neutrophils in BALF in a rat model of ischemia-reperfusion lung injury. In addition, the number of M2-like macrophages and T-regulatory lymphocytes in BALF fluid was increased in MSC-CM pretreated rats [82].

Likewise, in a mouse model of asthma, Ionescu et al. demonstrated that local delivery of CM derived from plastic-adherent bone marrow cells (BMC) is effective in reducing the number of pro-inflammatory cells in the lungs and airway hyper-responsiveness while increasing the percentage of IL-10 producing T-regulatory lymphocytes and macrophages. CM derived from lung fibroblasts did not produce the same effect as BMC-CM. Interestingly, adiponectin, an anti-inflammatory cytokine found in BMC-CM but not in fibroblast-CM, was shown to play a major role in conferring the protective effects of BMC-CM [83].

Additionally, the beneficial role of $\mathrm{MSC}-\mathrm{CM}$ in protecting lung tissue from hyperoxia was studied in several small animal models of bronchopulmonary dysplasia (BPD). BPD and consequent pulmonary hypertension are serious complications in premature infants caused by mechanical ventilation and oxygen toxicity. As reported by Aslam and colleagues hyperoxia-induced BPD in neonatal mice can be prevented by IV administration of concentrated mouse MSC-CM similar to MSC treatment. This study also revealed that early administration of MSC-CM significantly decreased right ventricular hypertrophy and muscularization of intrapulmonary arterioles as well as preserved the number of alveoli with normal morphology in neonatal mice exposed to hyperoxia. In parallel, MSC-CM treatment was shown to dramatically reduce the number of inflammatory cells and cytokine levels in BALF of injured mice. Another important finding was reflected in the identification of two immunomodulatory molecules, osteopontin (Spp1 or Opn) and macrophage-colony-stimulating factor 1 (M-CSF or Csf1), exclusively present in higher extent in the MSC-CM. This suggests their plausible role in the therapeutic benefits of MSC-CM [71]. In a separate study from the same group, Hansmann observed that MSC-CM could also reverse the adverse effects of long-term exposure to hyperoxia on lung morphology and function [84]. With a view to identifying the mechanisms by which MSC-CM function, Tropea et al. observed that systemic administration of MSCs and their $\mathrm{CM}$ increased the number of bronchoalveolar stem cells (BASCs) in terminal bronchioles of lungs of neonatal mice 10 days post administration. Similarly, MSC-CM enhanced BASC colony growth in vitro; however, supplementation of BASC cultures with growth factors known to be present in MSC-CM (VEGF, HGF, KGF, or basic FGF) did not show a similar effect, thus ruling out the association of these MSC components in enhanced BASC colony growth [85]. It is noteworthy that the effect of daily administration of human MSC-CM, intraperitoneally, was observed to be comparable with a single administration of MSCs in protecting neonatal rats from BPD and pulmonary hypertension [86]. Since culture conditions can influence the secretion pattern of MSCs, Waszak and colleagues examined the effect of hyperoxia on the therapeutic potential of preconditioned MSC-CM in a rat model of BPD. Preconditioning MSCs under $95 \% \mathrm{O}_{2}$ improved therapeutic benefits of the $\mathrm{CM}$ compared with control MSC-CM or lung fibroblast-CM. Correlatively, the preconditioned MSC-CM was also shown to contain a higher amount of STC-1 [87], which is a pleiotropic protein with antioxidant, anti-apoptotic, and anti-inflammatory potential [37, 88-90].

Shen and colleagues examined the anti-apoptotic and anti-fibrotic benefits of MSC-CM in a chronic model of bleomycin-induced lung injury. Histological analysis of MSC-CM-treated rats revealed a significant reduction in lung fibrosis and apoptosis 28 days post-injury. Interestingly, the MSC-CM was able to promote proliferation and prevent apoptosis of human non-small cell lung cancer epithelial cells in vitro [76].

The therapeutic benefits of MSC-CM were also evaluated in a small animal model of cigarette-smoke-induced COPD. In addition to lung emphysema, cigarette smoke can cause apoptosis in lung fibroblasts. One of the roles of lung fibroblasts is to maintain the integrity of the alveolar structure; thus, their normal function is essential for the regeneration of the injured lung. Huh et al. showed that MSC and MSC-CM treatment significantly improved the histology of the emphysematous lungs and increased the number of small pulmonary vessels [91]. In a separate study, Kim et al. reported that MSC-CM reduced lung fibroblast apoptosis and increased their proliferation in vitro and in vivo. MSC-CM also restored the expression of extracellular matrix proteins and collagen gel contraction mediated at least in part by the PI3K/Akt pathway. Interestingly, the presence of both anti- and pro-fibrotic mediators was detected in MSC-CM [92].

Overall, these reports strongly suggest that administration of CM derived from MSCs can significantly attenuate cell 
death and inflammatory responses while improving tissue healing and endogenous regeneration in various lung injury models. However, the key mediators and the optimal conditions to produce them are still largely unknown.

\section{Therapeutic potential of MSC-EVs in lung injury}

Among the potential key mediators of MSCs, MSC-EVs are considered to bear therapeutic potential in lung injury. In order to establish a safe and effective alternative to live-cell transplantation, the therapeutic potential of different EV fractions was examined in a variety of preclinical animal models of lung injury as summarized in Table 3.

Gennai and colleagues used an ex vivo lung perfusion model to demonstrate the effect of MSC-EVs on alveolar fluid clearance rate in human lungs rejected for transplantation. MSC-EVs improved alveolar fluid clearance rate in a dose-dependent manner. Lung weight gain was also reduced by MSC-EV therapy compared to perfusion alone. Conversely, EVs derived from normal human lung fibroblasts had no beneficial effects. Further, MSC-EVs restored tracheal pressure, improved lung compliance, and reduced pulmonary artery pressure over six hours. The amount of lactate was also significantly lower in MSC-EV treated lungs compared to the control lungs. Since the anti-CD44 antibody attenuated the uptake of EVs by alveolar epithelial cells, the study suggested a key role of the CD44 receptor in internalizing EVs into recipient cells [93].

The studies on exploring therapeutic benefits of MSC-EVs have been examined in several ALI models. In this regard, an investigation by Zhu and colleagues recently showed that IT administration of MSC-EVs was associated with a reduction in pulmonary edema in $E$. coli endotoxin-induced ALI in mice. Additionally, MSC-EVs attenuated the influx of inflammatory cells and the presence of macrophage inflammatory protein 2 (MIP-2) in the alveoli. Both IT and IV administration of MSC-EVs were shown to dramatically increase the amount of KGF in BALF compared to injured untreated mice, maybe via transfer of KGF mRNA [22]. In another study, Li et al. preconditioned MSCs under anoxia for 60 min prior EV collection. Subsequently, EVs from both normal culture and preconditioned MSCs were observed to significantly reduce the total number of white blood cells, neutrophils, total proteins, and MIP-2 in BALF of endotoxin-injured mice; however, no significant differences were observed between the preconditioned MSC-EVs and control MSC-EVs [94].

Another report by Monsel and colleagues demonstrated that systemic administration of MSC-EVs improved survival and reduced lung inflammation and injury while promoting bacterial clearance in a murine model of $E$. coli-induced pneumonia. EVs harvested from MSCs preconditioned with a toll-like receptor (TLR)-3 agonist were shown to further increase KGF secretion and bacterial clearance. When examined in vitro, the MSC-EVs increased the phagocytic function of human macrophages and the ATP levels in alveolar epithelial type 2 cells. Preconditioned MSC-EVs were more effective in enhancing the anti-inflammatory and phagocytic activity of cultured macrophages, possibly by transferring cyclooxygenase- 2 mRNA to activated monocytes resulting in an increase in production of PGE2 [95].

The direct effects of MSC-EVs on activated macrophages has also been studied by preconditioning alveolar macrophages (AMs) with MSC-EVs and administering them to mice with LPS-induced lung injury. Administration of pretreated AMs, but not control AMs, significantly reduced total proteins, TNF- $\alpha$, and the total number of neutrophils in BALF. Mitochondrial transfer via MSC-EVs was shown to play an important role in carrying the anti-inflammatory and pro-phagocytic effects of MSCs on macrophages [96]. Phinney and colleagues demonstrated that under oxidative stress, MSCs donated mitochondria to macrophages via EVs. In addition, they revealed that IV administration of MSCs or their EVs in silica-exposed mice significantly reduced the infiltration of white blood cells and secretion of inflammatory mediators in BALF. MSCs and their EVs also reduced the size of the calcified nodules as well as the expression of pro-inflammatory [TNF, CCL2, and chemokine (C-X-C motif) ligand (CXCL) 1] and pro-fibrotic (TGF- $\beta$ and IL-10) genes in the lung, 2 to 4 weeks post-injury. Interestingly, MSC-EVs, but not MSCs alone, reduced the accumulation of hydroxyproline in lung tissue [17]. Systemic administration of MSCs or EVs following silica exposure was shown to decrease collagen deposition in lung parenchyma and recruitment of neutrophils and lymphocytes into airways two weeks post-treatment. However, MSC-EV administration did not significantly reduce lung wet-to-dry ratio, as opposed to MSCs [97].

The therapeutic benefits of MSC-CM and MSC-EVs were compared in a mouse model of acute asthma. Systemic administration of both MSC-CM and EVs, but not lung fibroblast products, significantly abrogated the increase in airway hyper-responsiveness and lung inflammation. The amounts of $\mathrm{T}$ helper lymphocyte (Th)2and Th17-associated cytokines were reduced in BALF while IL-10 levels were concomitantly increased. Blocking the release of secreted mediators in MSCs in vitro suppressed many protective effects of the cells [75].

In a murine model of hemorrhagic shock, MSCs and their EVs were shown to attenuate vascular permeability in injured lungs. Both treatments were able to suppress hemorrhagic-shock-induced RhoA GTPase activity in lungs. MSC-CM and recombinant angiopoietin 1 (Ang1), 
Table 3 Summary of therapeutic benefits of MSC-EVs in preclinical animal models

\begin{tabular}{|c|c|c|c|c|c|}
\hline EV Source & Route & Injury Model & Outcomes & Key Factor & Ref. \\
\hline Human BM-MSC & IT, IV & Mouse-ALI/LPS & $\begin{array}{l}\downarrow \text { Lung edema } \\
\downarrow \text { WBCs \& neutrophils in BALF } \\
\downarrow \text { Total protein \& MIP-2 in BALF } \\
\uparrow \text { KGF in BALF }\end{array}$ & KGF mRNA & $\overline{\text { [22] }}$ \\
\hline $\begin{array}{l}\text { Normoxia \& Anoxia pretreated } \\
\text { Human BM-MSC }\end{array}$ & IV & Mouse-ALI/LPS & $\begin{array}{l}\downarrow \text { WBCs \& neutrophils in BALF } \\
\downarrow \text { Total protein \& MIP-2 in BALF }\end{array}$ & & [94] \\
\hline $\begin{array}{l}\text { Untreated \& Poly }(I: C) \text {-pretreated } \\
\text { Human BM-MSC }\end{array}$ & IT, IV & Mouse-Pneumonia/E. coli & $\begin{array}{l}\downarrow \text { Lung injury } \\
\downarrow \text { WBCs \& neutrophils in BALF } \\
\downarrow \text { Total protein \& MIP-2 in BALF } \\
\downarrow \text { E. coli count in BALF, lung, \& blood } \\
\uparrow \text { Survival } \\
\uparrow \text { KGF in BALF }\end{array}$ & $\begin{array}{l}\text { KGF mRNA } \\
\& \text { CD44 }\end{array}$ & [95] \\
\hline Human BM-MSC & $\begin{array}{l}\text { EV-treated AM/ } \\
\text { IN }\end{array}$ & Mouse-ALI/LPS & $\begin{array}{l}\downarrow \text { Neutrophils in BALF } \\
\downarrow \text { Total protein \& TNF-a in BALF }\end{array}$ & Mitochondria transfer & [96] \\
\hline Human BM-MSC & IV & Mouse-Shock/Hemorrhage & $\begin{array}{l}\downarrow \text { Vascular permeability } \\
\downarrow \text { RhoA GTPase activity in lung }\end{array}$ & & [66] \\
\hline Human WJ-MSC & IT & Mouse-Lung Injury/l/R & $\begin{array}{l}\downarrow \text { Lung edema } \\
\downarrow \text { Airway resistance } \\
\downarrow \text { Pulmonary artery pressure } \\
\downarrow \text { Neutrophil in lung } \\
\downarrow \text { Inflammatroy cytokines in BALF } \\
\uparrow \text { KGF, PGE2, \&lL-10 in BALF }\end{array}$ & & [115] \\
\hline Swine BM-MSC & IT & Swine-Influenza/SwIV & $\begin{array}{l}\downarrow \text { Lung lesions } \\
\downarrow \text { WBCs in lung } \\
\downarrow \text { Inflammatory cytokines in lung } \\
\downarrow \text { Virus titer in nasal swap \& lung }\end{array}$ & RNA & [101] \\
\hline Mouse \& Human BM-MSC & IV & Mouse-Asthma/AHE & $\begin{array}{l}\downarrow \text { Airway hyper-responsiveness } \\
\downarrow \text { WBCs in BALF \& lung } \\
\downarrow \text { Th2/Th17 related cytokines in BALF }\end{array}$ & & {$[75]$} \\
\hline Mouse BM-MSC & IV & Mouse-PAH/Hypoxia & $\begin{array}{l}\downarrow \text { Right ventricular systolic pressure } \\
\downarrow \text { Vascular remodeling } \\
\downarrow \text { Macrophages \& cytokines in lung } \\
\downarrow \text { STAT-3 in lung }\end{array}$ & & [20] \\
\hline Rat BM-MSC & IV & Rat-PAH/Monocrotaline & $\begin{array}{l}\downarrow \text { Pulmonary artery pressure } \\
\downarrow \text { Pulmonary vascular remodeling } \\
\downarrow \text { Right ventricle pressure } \\
\downarrow \text { Right ventricular hypertrophy }\end{array}$ & & [98] \\
\hline Mouse \& Human BM-MSC & IV & Mouse-PAH/ Monocrotaline & $\begin{array}{l}\downarrow \text { Pulmonary vascular remodeling } \\
\downarrow \text { Right ventricle hypertrophy }\end{array}$ & miRNAs & [99] \\
\hline Human WJ- \& BM-MSC & IV & $\begin{array}{l}\text { Neonatal Mouse-BPD/ } \\
\text { Hyperoxia }\end{array}$ & $\begin{array}{l}\uparrow \text { Alveolarization } \\
\uparrow \text { Lung funcion } \\
\downarrow \text { Lung fibrosis } \\
\downarrow \text { PAH } \\
\downarrow \text { Pulmonary vasular remodeling } \\
\downarrow \text { Pro-inflammatry genes in } \\
\text { macrophages }\end{array}$ & & [67] \\
\hline Human UC-MSC & IT & Neonatal Rat-BPD/Hyperoxia & $\begin{array}{l}\uparrow \text { Alveolarization \& angiogenesis } \\
\downarrow \text { Alveolar epithelial cell death } \\
\downarrow \text { Macrophages \& cytokines in lung }\end{array}$ & VEGF & [100] \\
\hline Human BM-MSC & IV & Mouse-Lung Fibrosis/Silica & $\begin{array}{l}\downarrow \text { Size of calcified nodules in lung } \\
\downarrow \text { Hydroxyproline in lung } \\
\downarrow \text { Inflammatory cells in BALF } \\
\downarrow \text { Cytokines in BALF }\end{array}$ & $\begin{array}{l}\text { miRNAs \& mitochondria } \\
\text { transfer }\end{array}$ & [17] \\
\hline Human BM-MSC & IV & Mouse-Lung Fibrosis/Silica & $\begin{array}{l}\downarrow \text { Lung collagen } \\
\downarrow \text { WBCs in BALF }\end{array}$ & & [97] \\
\hline Human ASCs & IT & Mouse-COPD/ elastase & $\begin{array}{l}\downarrow \text { Lung emphysema } \\
\uparrow \text { FGF2 in lung }\end{array}$ & & [116] \\
\hline
\end{tabular}

$A H E$ - Aspergillus hyphal extract, $A L I$ - acute lung injury, $A M$ - Alveolar macrophages, $A S C S$ - adipose-derived mesenchymal stem cells, BALF - bronchoalveolar lavage fluid, BM-MSC - bone marrow-derived mesenchymal stem cells, FGF2 - fibroblast growth factor $2, I L-10$ - interleukin $10, I N$ - intranasal, $I / R$ - ischemia reperfusion, IT - intratracheal, $I V$ - intravenous, KGF - keratinocyte growth factor, LPS - lipopolysaccharide, MIP-2 - macrophage inflammatory protein 2, miRNAs microRNAs, OVA - ovalbumin, PAH - pulmonary artery hypertension, PGE2 - prostaglandin E2, STAT-3 - signal transducer and activator of transcription 3, SWIV swine influanza virus $\mathrm{H} 1 \mathrm{N1}$, Th - T helper lymphocyte, UC-MSC - umbilical cord blood-MSC, VEGF - vascular endothelial growth factor, WBCS - white blood cells, WJ-MSC - umbilical cord Wharton's jelly-MSC 
but not EVs, significantly protected endothelial VE-cadherin junctions and reduced permeability in vitro. In vivo analysis of protein phosphorylation patterns also revealed some differences in signaling pathways activated by MSC-EVs compared to MSCs. Overall, these observations suggest that while MSC-EVs preserved pulmonary vasculature integrity similar to MSCs, their mechanism of action was not necessarily equivalent [66].

The effect of MSC-EVs on pulmonary vasculature was also demonstrated by Lee and colleagues. Studies by this group indicated that the administration of MSC-EVs, but not fibroblast-EVs, can protect against the elevation of right ventricular systolic pressure and pulmonary vascular remodeling in a murine model of hypoxia-induced pulmonary artery hypertension. The MSC-EVs mediated an anti-inflammatory effect by reducing the influx of lung macrophages and early inflammatory mediators. MSC-EV treatment also abrogated the hypoxia-induced phosphorylation of signal transducer and activator of transcription 3 (STAT-3), which plays a critical role in the response of pulmonary vasculature to hypoxia [20]. In a rat model of monocrotaline-induced pulmonary hypertension, IV administration of rat MSC-EVs decreased pulmonary artery pressure and remodeling as well as right ventricle pressure and hypertrophy. MSC-EVs were as effective as their parent cells in preventing pulmonary hypertension [98]. Similarly, IV administration of either mouse or human MSC-EVs was shown to reduce right ventricular hypertrophy and pulmonary vascular remodeling in monocrotaline-treated mice. Administration of the exosome fraction of MSC-EVs exerted higher therapeutic response compared to the microvesicle fraction. MicroRNA analysis revealed a significant increase in the levels of several anti-inflammatory and anti-proliferative microRNAs, including miRs-34a,-122,-124, and -127 in MSC-exosomes compared to exosomes derived from plasma of healthy mice [99].

Similar to MSC-CM, MSC-EVs were shown to significantly reduce lung fibrosis, restore lung architecture, and improve alveolarization and lung function of neonatal mice exposed to $75 \%$ oxygen for 7 days. MSC-EV administration also reduced pulmonary arterial remodeling and hypertension associated with BPD. Additionally, MSC-EVs downregulated expression of genes associated with pro-inflammatory macrophages [67]. In a study conducted by Ahn and colleagues, EVs derived from UC-MSCs were as effective as their parental cells in preventing hypoxia-induced BPD in neonatal rats. Also, MSCs and their EVs reduced the inflammatory responses in the lungs in contrary to fibroblast-derived EVs that did not exhibit similar protective effects. Finally, the protective effect rendered by MSCs and EVs was partially abrogated by the knockdown of the VEGF gene in MSCs prior to EV isolation [100].
Recently, MSC-EVs were examined in a swine model of influenza virus-induced ALI. Local administration of MSC-EVs was able to significantly reduce the infiltration of inflammatory cells to the lungs, the thickening of alveolar walls, and the number of collapsed alveoli in infected swine. MSC-EVs were also able to reduce replication and shedding of influenza virus both in vivo and in vitro. It was suggested that the transfer of RNA to the infected cells might be an important factor in the observed anti-influenza activity by MSC-EVs [101].

Overall, cumulative studies described above suggest that in order to increase cell survival, preserve physiological function, and reduce immune/inflammatory responses, MSC-EVs can transfer bioactive mediators to injured cells and regulate their pathophysiologic responses. In most experiments, EVs appeared to be as potent as MSCs, possibly with lower health-associated risks.

\section{MSC-EVs: From bench to bedside}

In 2014, allogeneic MSC-EVs were administered to a patient with a steroid refractory graft-versus-host disease (GvHD). Not only the diarrhea volume of the patient was reduced after MSC-EV therapy, but also cutaneous and mucosal symptoms were improved within two weeks and the patient was in stable condition four months after EV treatments. Consequently, the dose of steroids given to the patient was reduced. Interestingly, the number of patient's peripheral blood mononuclear cells producing TNF- $\alpha$, IL- $1 \beta$, or IFN- $\gamma$ was reduced more than $50 \%$ after the last EV administration [102].

In a separate study, forty patients with chronic kidney disease (CKD) were randomly divided into two groups to receive MSC-EVs or placebo treatment. Two doses of MSC-EVs were administered a week apart. The first dose was administered IV and the second intra-arterially. Of note, MSC-EV treatment, but not the placebo, was effective in improving estimated glomerular filtration rate and urinary albumin-to-creatinine ratio as well as reducing serum creatinine and blood urea. At twelve weeks after EV treatment, plasma levels of TNF- $\alpha$ were significantly reduced, whereas levels of IL-10 and TGF- $\beta$ were increased [103]. In both studies, the MSC-EV administration was well-tolerated by patients without any side effects.

A phase II/III clinical trial is currently registered on clinicaltrials.gov evaluating the benefits of UC-MSC-EVs in type I diabetic patients [104]. In addition, recently, an Investigational New Drug clearance for allogeneic MSC-EVs was approved by the Food and Drug Administration for the treatment of severe second-degree burn patients. The company that received the approval is planning to conduct a multicenter phase I/IIa clinical trial in late 2018 [105]. 


\section{Conclusions}

Overall, current data suggest that MSC-derived products can effectively mimic the therapeutic effects of MSCs in preclinical models of lung injury. The use of CM or EVs may circumvent many of the safety concerns associated with the use of live cells, such as thrombogenicity. Also, unlike cells, CM and EVs are not able to proliferate or reprogram after administration, which decreases the risk of tumorigenicity [106-108]. From a therapeutic standpoint, MSC-EVs and other bioactive mediators are smaller than their parent cells, and thus might be distributed more efficiently into the lungs and other organs.

Another therapeutic advantage of EVs arises from their ability to protect their cargo from unfavorable environmental conditions, such as dramatic changes in $\mathrm{pH}$ or release of digestive (lytic) enzymes into the bloodstream and damaged tissue. Based on this concept, MSC-EVs are considered efficient vehicles for transporting delicate bioactive mediators to the distal airways. It is also thought that MSC-EVs can be used to deliver specific drugs to target organs. Such drugs can be delivered to EVs via MSCs that overexpress those factors, or can be loaded directly to the EVs after they have been released by the cells. Examples of different types of therapeutic cargo include siRNAs for silencing target genes and chemotherapeutic drugs, such as doxorubicin [109, 110].

In addition to their biological advantages, feasibility/ logistical advantages set cell-free products apart. For instance, large-scale manufacturing of cell-free products is possible by repeated harvesting of $\mathrm{CM}$ from cultured MSCs. MSC-CM and EVs can be prepared and stored in small volumes, which could simplify dosing studies. Another great advantage is that $\mathrm{CM}$ and EVs can also be stored for several months at $-20{ }^{\circ} \mathrm{C}$ to $-80{ }^{\circ} \mathrm{C}$ without the need for cryopreservatives, unlike their parent cells [111]. Notably, cryopreservatives, such as dimethyl sulfoxide (DMSO), can be cytotoxic and have been reported to lyse EVs [112]. The potential capability to freeze-dry and lyophilize all or pertinent fractions of CM and EVs should be helpful in overcoming the logistical difficulties of storage and transport of these products in austere conditions.

There appear to be therapeutic advantages in using MSC-CM and EVs over live whole cells; yet, to develop safe and effective cell-free therapies, a significant knowledge gap needs to be addressed, including optimization of bioactive components, dosing regimens, and production methods. A growing number of studies have identified some of the key mediators in MSC-CM and EVs; however, there is a variability in the content of the secretome due to several factors. These include donor's condition (age, sex, and health status), the type of MSCs (e.g. bone marrow, adipose, or $\mathrm{UC}$ ), the type of culture (flask or bioreactor), the type of media and supplements (e.g., fetal bovine serum, xeno-free, or chemically-defined media), and the microenvironment (e.g. oxygen tension and presence or absence of stress signals) $[16,104,111]$. Also, post-processing of CM and EVs (e.g. CM concentration and EV enrichment) as well as handling and storage can influence their quality [111]. Furthermore, various factors (e.g. methods of EV enrichment and storage) could influence the quantity of EVs present in the final product [104], making it difficult to estimate EV yield per MSC. In light of these limitations, it is essential to develop a series of potency assays for cell-free products in order to control their quality and quantity, and to predict their efficacy in vivo.

Based on currently available techniques, large numbers of MSCs are still required to produce an adequate amount of CM or EVs for clinical use, similar to the number of MSCs used for clinical trials (e.g. $10^{6}-10^{7}$ cells $/ \mathrm{kg}$ ). In order to produce sufficient pools of MSCs, the cells need to be expanded in vitro for several population doublings. Although MSCs have been shown to be safe for up to 40 population doublings [16], it is important to frequently inspect them for cell senescence and chromosome instability, and eliminate defective cells. To overcome the low yield of MSCs and their products from primary cultures, genetic modification, such as immortalization, can be considered [113]. In addition, the technology to obtain CM and EVs from MSCs derived from induced pluripotent stem cells (iPSC-MSCs) might be beneficial $[111,114]$. iPSC-MSCs have robust proliferation and differentiation capacities and can be generated either from allogeneic sources or patients [114]. These alternative approaches could also facilitate establishing universal donors to minimize donor-to-donor variability and produce large-scales of CM and EVs with consistent quality. The use of autologous MSCs and their products may be considered when allogeneic products are not available, especially in remote and austere conditions. However, since the effect of different disorders on endogenous stem cells and their products is not completely understood $[16,111]$, the application of autologous-based products needs to be carefully assessed.

To summarize, MSC-CM and EVs emerge as promising therapeutic tools for the treatment of acute and chronic lung diseases. However, there is a compelling need to gather additional knowledge. Furthermore, large-scale production of Good Manufacturing Practice (GMP)-graded MSC-CM and EVs needs to be developed so that cell-free therapy can be safely translated from the bench to the bedside.

\section{Abbreviations}

AEC: Alveolar Epithelial Cell; AHE: Aspergillus Hyphal Extract; ALI: Acute Lung Injury; Alix: Apoptosis-Linked Gene (ALG)-2-Interacting Protein X; AM: Alveolar Macrophages; Ang1: Angiopoietin 1; APN: Adiponectin; ARDS: Acute Respiratory Distress Syndrome; ASC: Adipose-derived Mesenchymal Stem/ stromal Cell; BALF: Bronchoalveolar Lavage Fluid; BASCs: Bronchoalveolar Stem Cells; BMC: Bone Marrow Cells; BPD: Bronchopulmonary Dysplasia; CCL: Chemokine (C-C motif) ligand; CKD: Chronic kidney disease; 
CM: Conditioned Media; COPD: Chronic Obstructive Pulmonary Disease; CXCL: Chemokine (C-X-C motif) ligand; CXCR: Chemokine (C-X-C motif) Receptor; DMSO: Dimethyl sulfoxide; E.coli: Escherichia coli; EGFr: Epidermal Growth Factor Receptor; EVs: Extracellular Vesicles; FGF: Fibroblast Growth Factor; G-CSF: Granulocyte Colony Stimulating Factor; GM-CSF: Granulocyte Monocyte Colony Stimulating Factor; GMP: Good Manufacturing Practice; GvHD: Graft-versus-Host Disease; HGF: Hepatocyte Growth Factor; HLADR: Human Leukocyte Antigen; HO-1: Hemeoxygenase 1; I/R: Ischemia Reperfusion; IDO: Indoleamine 2,3-Dioxygenase; IFN- $\gamma$ : Interferon Gamma; IGF-1: Insulin-like Growth Factor 1; IL: Interleukin; IL-1 ra: IL-1 Receptor Antagonist; iPSC-MSC: Induced Pluripotent Stem Cell-derived Mesenchymal Stem/stromal Cell; IN: Intranasal; iNOS: Inducible Nitric Oxide Synthase; IPF: Idiopathic Pulmonary Fibrosis; IT: Intratracheal; IV: Intravenous; KGF: keratinocyte Growth Factor; LIF: Leukemia Inhibitory Factor; LPS: Lipopolysaccharide; M2: Alternatively Activated Macrophages; MCP1: Monocyte Chemotactic Protein 1; M-CSF (Csf1): Macrophage-Colony Stimulating Factor 1; MIP-2: Macrophage Inflammatory Protein 2; miRNA (miR): MicroRNA; MMP: Metalloproteinase; mRNA: Messenger RNA; MSCs: mesenchymal stem/stromal cells; MVBs: Multi-Vesicular Bodies; NTA: Nanoparticle Tracking Analysis.; Opn: (Spp1) Osteopontin.; OVA: Ovalbumin.; PAH: Pulmonary Artery Hypertension.; PDGF: Platelets Derived Growth Factor.; PGE2: Prostaglandin E2.; PS: Phosphatidylserine.; SDF1: Stem Cell-Derived Factor 1.; siRNA: Small Interference RNA.; STAT-3: Signal transducer and activator of transcription 3.; STC-1: Stanniocalcin-1.; SWIV: Swine Influenza Virus H1N1.; TGF- $\beta$ : Transforming Growth Factor beta:; Th: T Helper Lymphocyte.; TIMP-1: Tissue Inhibitor of Metalloproteinase 1.; TLR: Toll-like Receptor.; TNF-a: Tumor Necrosis Factor Alpha.; Treg: Regulatory T Lymphocyte.; Tsg 101: Tumor Susceptibility Gene 101.; TSG-6: TNF Stimulating Gene 6 Protein.; UC-MSC: Umbilical Cord Blood Mesenchymal Stem/stromal Cell.; VEGF: Vascular Endothelial Growth Factor.; WBC: White Blood Cell.; WJ-MSC: Umbilical Cord Warton's Jelly Mesenchymal Stem/ stromal Cell.

\section{Acknowledgements}

The authors wish to thank the personnel of the Multi-Organ Support Technology (MOST) Task Area. Additionally, the authors would like to thank Dr. Subrata Haldar for reviewing and editing of the manuscript.

\section{Funding}

This work was supported by USAMRMC Combat Casualty Care RAD administered via the Multi-Organ Support Technology (MOST) Task Area, Grant number:

X_017_2018; Pl: Arezoo Mohammadipoor.

\section{Availability of data and materials}

Not Applicable.

\section{Disclaimer}

The opinions or assertions contained herein are the private views of the authors and are not to be construed as official or as reflecting the views of the Department of the Army or the Department of Defense.

\section{Authors' contributions}

A.M. contributed to the design and writing of the manuscript. B.A. contributed to the writing and critical revisions of the manuscript. A.B. contributed to the critical revisions. L.C. contributed to the funding and critical revisions. All authors read and approved the final manuscript.

\section{Ethics approval and consent to participate}

Not Applicable.

\section{Consent for publication}

Not Applicable.

\section{Competing interests}

The authors declare that they have no competing interests.

\section{Publisher's Note}

Springer Nature remains neutral with regard to jurisdictional claims in published maps and institutional affiliations.

\section{Author details}

'Multi-Organ Support Technology (MOST) Task Area, US Army Institute of Surgical Research, Fort Sam Houston, TX, USA. ${ }^{2}$ Oak Ridge Institute for Science and Education, Oak Ridge, TN, USA. ${ }^{3}$ The Geneva Foundation, Tacoma, WA, USA

Received: 3 July 2018 Accepted: 23 October 2018

Published online: 09 November 2018

\section{References}

1. Sueblinvong V, Weiss DJ. Stem cells and cell therapy approaches in lung biology and diseases. Transl Res. 2010;156(3):188-205.

2. Rubenfeld GD, Caldwell E, Peabody E, Weaver J, Martin DP, Neff M, Stern EJ, Hudson LD. Incidence and outcomes of acute lung injury. N Engl J Med. 2005;353(16):1685-93.

3. Matthay MA, Ware LB, Zimmerman GA. The acute respiratory distress syndrome. J Clin Invest. 2012;122(8):2731-40.

4. Przybysz TM, Heffner AC. Early treatment of severe acute respiratory distress syndrome. Emerg Med Clin North Am. 2016;34(1):1-14.

5. Batchinsky Al, Burkett SE, Zanders TB, Chung KK, Regn DD, Jordan BS, Necsoiu C, Nguyen R, Hanson MA, Morris MJ, et al. Comparison of airway pressure release ventilation to conventional mechanical ventilation in the early management of smoke inhalation injury in swine. Crit Care Med. 2011; 39(10):2314-21.

6. Batchinsky Al, Weiss WB, Jordan BS, Dick EJ Jr, Cancelada DA, Cancio LC. Ventilation-perfusion relationships following experimental pulmonary contusion. J Appl Physiol (1985). 2007;103(3):895-902.

7. The acute respiratory distress syndrome network. Ventilation with lower tidal volumes as compared with traditional tidal volumes for acute lung injury and the acute respiratory distress syndrome. N Engl J Med. 2000; 342(18):1301-8.

8. Ranieri VM, Rubenfeld GD, Thompson BT, Ferguson ND, Caldwell E, Fan E, Camporota L, Slutsky AS. Acute respiratory distress syndrome: the Berlin definition. Jama. 2012;307(23):2526-33.

9. Kreyer S, Scaravilli V, Linden K, Belenkiy SM, Necsoiu C, Li Y, Putensen C, Chung KK, Batchinsky Al, Cancio LC. Early utilization of extracorporeal CO2 removal for treatment of acute respiratory distress syndrome due to smoke inhalation and burns in sheep. Shock. 2016;45(1):65-72.

10. Ortiz LA, Dutreil M, Fattman C, Pandey AC, Torres G, Go K, Phinney DG. Interleukin 1 receptor antagonist mediates the antiinflammatory and antifibrotic effect of mesenchymal stem cells during lung injury. Proc Natl Acad Sci U S A. 2007;104(26):11002-7.

11. Xu J, Woods CR, Mora AL, Joodi R, Brigham KL, lyer S, Rojas M. Prevention of endotoxin-induced systemic response by bone marrow-derived mesenchymal stem cells in mice. Am J Physiol Lung Cell Mol Physiol. 2007; 293(1):L131-41.

12. Gupta N, Su X, Popov B, Lee JW, Serikov V, Matthay MA. Intrapulmonary delivery of bone marrow-derived mesenchymal stem cells improves survival and attenuates endotoxin-induced acute lung injury in mice. J Immunol. 2007:179(3):1855-63.

13. Qin ZH, Xu JF, Qu JM, Zhang J, Sai Y, Chen CM, Wu L, Yu L. Intrapleural delivery of MSCs attenuates acute lung injury by paracrine/endocrine mechanism. J Cell Mol Med. 2012;16(11):2745-53.

14. Curley GF, Hayes M, Ansari B, Shaw G, Ryan A, Barry F, O'Brien T, O'Toole D, Laffey JG. Mesenchymal stem cells enhance recovery and repair following ventilator-induced lung injury in the rat. Thorax. 2012;67(6):496-501

15. Antunes MA, Abreu SC, Cruz FF, Teixeira AC, Lopes-Pacheco M, Bandeira E, Olsen PC, Diaz BL, Takyia CM, Freitas IP, et al. Effects of different mesenchymal stromal cell sources and delivery routes in experimental emphysema. Respir Res. 2014;15:118.

16. Antebi B, Mohammadipoor A, Batchinsky Al, Cancio LC. The promise of mesenchymal stem cell therapy for acute respiratory distress syndrome. J Trauma Acute Care Surg. 2018;84(1):183-91.

17. Phinney DG, Di Giuseppe M, Njah J, Sala E, Shiva S, St Croix CM, Stolz DB, Watkins SC, Di YP, Leikauf GD, et al. Mesenchymal stem cells use extracellular vesicles to outsource mitophagy and shuttle microRNAs. Nat Commun. 2015;6:8472.

18. Lai RC, Yeo RW, Lim SK. Mesenchymal stem cell exosomes. Semin Cell Dev Biol. 2015;40:82-8. 
19. Lai RC, Arslan F, Lee MM, Sze NS, Choo A, Chen TS, Salto-Tellez M, Timmers L, Lee CN, El Oakley RM, et al. Exosome secreted by MSC reduces myocardial ischemia/reperfusion injury. Stem Cell Res. 2010;4(3):214-22.

20. Lee C, Mitsialis SA, Aslam M, Vitali SH, Vergadi E, Konstantinou G, Sdrimas K, Fernandez-Gonzalez A, Kourembanas $\mathrm{S}$. Exosomes mediate the cytoprotective action of mesenchymal stromal cells on hypoxia-induced pulmonary hypertension. Circulation. 2012;126(22):2601-11.

21. Li T, Yan Y, Wang B, Qian H, Zhang X, Shen L, Wang M, Zhou Y, Zhu W, Li $W$, et al. Exosomes derived from human umbilical cord mesenchymal stem cells alleviate liver fibrosis. Stem Cells Dev. 2013;22(6):845-54.

22. Zhu YG, Feng XM, Abbott J, Fang XH, Hao Q, Monsel A, Qu JM, Matthay MA, Lee JW. Human mesenchymal stem cell microvesicles for treatment of Escherichia coli endotoxin-induced acute lung injury in mice. Stem cells. 2014;32(1):116-25.

23. Wang Y, Lu X, He J, Zhao W. Influence of erythropoietin on microvesicles derived from mesenchymal stem cells protecting renal function of chronic kidney disease. Stem Cell Res Ther. 2015;6:100.

24. Friedenstein AJ, Chailakhjan RK, Lalykina KS. The development of fibroblast colonies in monolayer cultures of Guinea-pig bone marrow and spleen cells. Cell Tissue Kinet. 1970;3(4):393-403.

25. Zuk PA, Zhu M, Ashjian P, De Ugarte DA, Huang Jl, Mizuno H, Alfonso ZC, Fraser JK, Benhaim P, Hedrick MH. Human adipose tissue is a source of multipotent stem cells. Mol Biol Cell. 2002;13(12):4279-95.

26. Miura M, Gronthos S, Zhao M, Lu B, Fisher LW, Robey PG, Shi S. SHED: stem cells from human exfoliated deciduous teeth. Proc Natl Acad Sci U S A. 2003;100(10):5807-12.

27. Lee MW, Choi J, Yang MS, Moon YJ, Park JS, Kim HC, Kim YJ. Mesenchymal stem cells from cryopreserved human umbilical cord blood. Biochem Biophys Res Commun. 2004;320(1):273-8.

28. In 't Anker PS, Scherjon SA, Kleijburg-van der Keur C, de Groot-swings GM, Claas FH, Fibbe WE, Kanhai HH. Isolation of mesenchymal stem cells of fetal or maternal origin from human placenta. Stem cells. 2004;22(7):1338-45.

29. Prockop DJ, Kota DJ, Bazhanov N, Reger RL. Evolving paradigms for repair of tissues by adult stem/progenitor cells (MSCS). J Cell Mol Med. 2010;14(9):2190-9.

30. Dominici M, Le Blanc K, Mueller I, Slaper-Cortenbach I, Marini F, Krause D, Deans R, Keating A, Prockop D, Horwitz E. Minimal criteria for defining multipotent mesenchymal stromal cells. The International Society for Cellular Therapy position statement. Cytotherapy. 2006;8(4):315-7.

31. Caplan Al, Dennis JE. Mesenchymal stem cells as trophic mediators. J Cell Biochem. 2006;98(5):1076-84.

32. Uccelli A, Moretta L, Pistoia V. Mesenchymal stem cells in health and disease. Nat Rev Immunol. 2008;8(9):726-36.

33. Matthay MA. Therapeutic potential of mesenchymal stromal cells for acute respiratory distress syndrome. Ann Am Thorac Soc. 2015;12(1):S54-7.

34. Konala VB, Mamidi MK, Bhonde R, Das AK, Pochampally R, Pal R. The current landscape of the mesenchymal stromal cell secretome: a new paradigm for cell-free regeneration. Cytotherapy. 2016;18(1):13-24.

35. Gunn WG, Conley A, Deininger L, Olson SD, Prockop DJ, Gregory CA. A crosstalk between myeloma cells and marrow stromal cells stimulates production of DKK1 and interleukin-6: a potential role in the development of lytic bone disease and tumor progression in multiple myeloma. Stem cells. 2006;24(4):986-91.

36. Hung SC, Pochampally RR, Chen SC, Hsu SC, Prockop DJ. Angiogenic effects of human multipotent stromal cell conditioned medium activate the PI3KAkt pathway in hypoxic endothelial cells to inhibit apoptosis, increase survival, and stimulate angiogenesis. Stem cells. 2007;25(9):2363-70.

37. Block GJ, Ohkouchi S, Fung F, Frenkel J, Gregory C, Pochampally R, DiMattia $G$, Sullivan DE, Prockop DJ. Multipotent stromal cells are activated to reduce apoptosis in part by upregulation and secretion of stanniocalcin-1. Stem cells. 2009;27(3):670-81.

38. Ren G, Zhao X, Zhang L, Zhang J, L'Huillier A, Ling W, Roberts Al, Le AD, Shi $S$, Shao C, et al. Inflammatory cytokine-induced intercellular adhesion molecule-1 and vascular cell adhesion molecule-1 in mesenchymal stem cells are critical for immunosuppression. J Immunol. 2010;184(5):2321-8.

39. Choi H, Lee RH, Bazhanov N, Oh JY, Prockop DJ. Anti-inflammatory protein TSG-6 secreted by activated MSCs attenuates zymosan-induced mouse peritonitis by decreasing TLR2/NF-kappaB signaling in resident macrophages. Blood. 2011;118(2):330-8.

40. Zhang HC, Liu XB, Huang S, Bi XY, Wang HX, Xie LX, Wang YQ, Cao XF, LV J, Xiao FJ, et al. Microvesicles derived from human umbilical cord mesenchymal stem cells stimulated by hypoxia promote angiogenesis both in vitro and in vivo. Stem Cells Dev. 2012;21 (18):3289-97.
41. Lai RC, Tan SS, Yeo RW, Choo AB, Reiner AT, Su Y, Shen Y, Fu Z, Alexander L, Sze SK, et al. MSC secretes at least 3 EV types each with a unique permutation of membrane lipid, protein and RNA. J Extracell Vesicles. 2016;5:29828

42. Nemeth K, Leelahavanichkul A, Yuen PS, Mayer B, Parmelee A, Doi K, Robey PG, Leelahavanichkul K, Koller BH, Brown JM, et al. Bone marrow stromal cells attenuate sepsis via prostaglandin $E(2)$-dependent reprogramming of host macrophages to increase their interleukin-10 production. Nat Med. 2009;15(1):42-9.

43. Bustos ML, Huleihel L, Meyer EM, Donnenberg AD, Donnenberg VS, Sciurba JD, Mroz L, McVerry BJ, Ellis BM, Kaminski N, et al. Activation of human mesenchymal stem cells impacts their therapeutic abilities in lung injury by increasing interleukin (IL)-10 and IL-1RN levels. Stem Cells TransI Med. 2013; 2(11):884-95.

44. Kim DS, Jang IK, Lee MW, Ko YJ, Lee DH, Lee JW, Sung KW, Koo HH, Yoo KH. Enhanced immunosuppressive properties of human mesenchymal stem cells primed by interferon-gamma. EBioMedicine. 2018;28:261-73.

45. van Poll D, Parekkadan B, Cho CH, Berthiaume F, Nahmias Y, Tilles AW, Yarmush ML. Mesenchymal stem cell-derived molecules directly modulate hepatocellular death and regeneration in vitro and in vivo. Hepatology. 2008:47(5):1634-43.

46. van Koppen A, Joles JA, van Balkom BW, Lim SK, de Kleijn D, Giles RH, Verhaar MC. Human embryonic mesenchymal stem cell-derived conditioned medium rescues kidney function in rats with established chronic kidney disease. PLoS One. 2012;7(6):e38746.

47. Chang CL, Leu S, Sung HC, Zhen YY, Cho CL, Chen A, Tsai TH, Chung SY, Chai $H T$, Sun CK, et al. Impact of apoptotic adipose-derived mesenchymal stem cells on attenuating organ damage and reducing mortality in rat sepsis syndrome induced by cecal puncture and ligation. J Transl Med. 2012;10:244.

48. Shrestha C, Zhao L, Chen K, He H, Mo Z. Enhanced healing of diabetic wounds by subcutaneous administration of human umbilical cord derived stem cells and their conditioned media. Int J Endocrinol. 2013;2013:592454.

49. Goolaerts A, Pellan-Randrianarison N, Larghero J, Vanneaux V, Uzunhan Y, Gille T, Dard N, Planes C, Matthay MA, Clerici C. Conditioned media from mesenchymal stromal cells restore sodium transport and preserve epithelial permeability in an in vitro model of acute alveolar injury. Am J Physiol Lung Cell Mol Physiol. 2014;306(11):L975-85.

50. Pawitan JA. Prospect of stem cell conditioned medium in regenerative medicine. Biomed Res Int. 2014;2014:965849.

51. Danieli P, Malpasso G, Ciuffreda MC, Cervio E, Calvillo L, Copes F, Pisano F, Mura M, Kleijn L, de Boer RA, et al. Conditioned medium from human amniotic mesenchymal stromal cells limits infarct size and enhances angiogenesis. Stem Cells Transl Med. 2015;4(5):448-58.

52. da Silva AF, Silva K, Reis LA, Teixeira VP, Schor N. Bone marrow-derived mesenchymal stem cells and their conditioned medium attenuate fibrosis in an irreversible model of unilateral ureteral obstruction. Cell Transplant. 2015;24(12):2657-66.

53. S ELA, Mager I, Breakefield XO, Wood MJ. Extracellular vesicles: biology and emerging therapeutic opportunities. Nat Rev Drug Discov. 2013;12(5):347-57.

54. McVey M, Tabuchi A, Kuebler WM. Microparticles and acute lung injury. Am J Physiol Lung Cell Mol Physiol. 2012;303(5):L364-81.

55. Quesenberry PJ, Goldberg LR, Aliotta JM, Dooner MS, Pereira MG, Wen S, Camussi G. Cellular phenotype and extracellular vesicles: basic and clinical considerations. Stem Cells Dev. 2014;23(13):1429-36.

56. Cocucci E, Racchetti $G$, Meldolesi J. Shedding microvesicles: artefacts no more. Trends Cell Biol. 2009;19(2):43-51.

57. Rani S, Ryan AE, Griffin MD, Ritter T. Mesenchymal stem cell-derived extracellular vesicles: toward cell-free therapeutic applications. Mol Ther. 2015;23(5):812-23.

58. Raposo G, Nijman HW, Stoorvogel W, Liejendekker R, Harding CV, Melief CJ, Geuze HJ. B lymphocytes secrete antigen-presenting vesicles. J Exp Med. 1996;183(3):1161-72

59. Ratajczak J, Miekus K, Kucia M, Zhang J, Reca R, Dvorak P, Ratajczak MZ. Embryonic stem cell-derived microvesicles reprogram hematopoietic progenitors: evidence for horizontal transfer of mRNA and protein delivery. Leukemia. 2006;20(5):847-56.

60. Valadi H, Ekstrom K, Bossios A, Sjostrand M, Lee JJ, Lotvall JO. Exosomemediated transfer of mRNAs and microRNAs is a novel mechanism of genetic exchange between cells. Nat Cell Biol. 2007;9(6):654-9.

61. Thery C. Exosomes: secreted vesicles and intercellular communications. F1000 Biol Rep. 2011;3:15. 
62. Kourembanas S. Exosomes: vehicles of intercellular signaling, biomarkers, and vectors of cell therapy. Annu Rev Physiol. 2015;77:13-27.

63. Yu B, Zhang X, Li X. Exosomes derived from mesenchymal stem cells. Int J Mol Sci. 2014;15(3):4142-57.

64. Abreu SC, Weiss DJ, Rocco PR. Extracellular vesicles derived from mesenchymal stromal cells: a therapeutic option in respiratory diseases? Stem Cell Res Ther. 2016;7(1):53.

65. Bruno S, Grange C, Deregibus MC, Calogero RA, Saviozzi S, Collino F, Morando L, Busca A, Falda M, Bussolati B, et al. Mesenchymal stem cellderived microvesicles protect against acute tubular injury. J Am Soc Nephrol. 2009;20(5):1053-67.

66. Potter DR, Miyazawa BY, Gibb SL, Deng X, Togaratti PP, Croze RH, Srivastava AK, Trivedi A, Matthay M, Holcomb JB, et al. Mesenchymal stem cell derived extracellular vesicles attenuate pulmonary vascular permeability and lung injury induced by hemorrhagic shock and trauma. J Trauma Acute Care Surg. 2017;84(2):245-56.

67. Willis GR, Fernandez-Gonzalez A, Anastas J, Vitali SH, Liu X, Ericsson M, Kwong A, Mitsialis SA, Kourembanas S. Mesenchymal stromal cell exosomes ameliorate experimental bronchopulmonary dysplasia and restore lung function through macrophage immunomodulation. Am J Respir Crit Care Med. 2017;197(1):104-16.

68. Collino F, Deregibus MC, Bruno S, Sterpone L, Aghemo G, Viltono L, Tetta C, Camussi G. Microvesicles derived from adult human bone marrow and tissue specific mesenchymal stem cells shuttle selected pattern of miRNAs. PLoS One. 2010;5(7):e11803.

69. Merino-Gonzalez C, Zuniga FA, Escudero C, Ormazabal V, Reyes C, NovaLamperti E, Salomon C, Aguayo C. Mesenchymal stem cell-derived extracellular vesicles promote angiogenesis: Potencial clinical application. Front Physiol. 2016;7:24.

70. Arslan F, Lai RC, Smeets MB, Akeroyd L, Choo A, Aguor EN, Timmers L, van Rijen HV, Doevendans PA, Pasterkamp G, et al. Mesenchymal stem cellderived exosomes increase ATP levels, decrease oxidative stress and activate PI3K/Akt pathway to enhance myocardial viability and prevent adverse remodeling after myocardial ischemia/reperfusion injury. Stem Cell Res. 2013;10(3):301-12.

71. Aslam M, Baveja R, Liang OD, Fernandez-Gonzalez A, Lee C, Mitsialis SA, Kourembanas $\mathrm{S}$. Bone marrow stromal cells attenuate lung injury in a murine model of neonatal chronic lung disease. Am J Respir Crit Care Med. 2009;180(11):1122-30.

72. Baglio SR, Rooijers K, Koppers-Lalic D, Verweij FJ, Perez Lanzon M, Zini N, Naaijkens B, Perut F, Niessen HW, Baldini N, et al. Human bone marrow- and adipose-mesenchymal stem cells secrete exosomes enriched in distinctive miRNA and tRNA species. Stem Cell Res Ther. 2015;6:127.

73. Dai W, Hale SL, Kloner RA. Role of a paracrine action of mesenchymal stem cells in the improvement of left ventricular function after coronary artery occlusion in rats. Regen Med. 2007;2(1):63-8.

74. Ionescu L, Byrne RN, van Haaften T, Vadivel A, Alphonse RS, Rey-Parra GJ, Weissmann G, Hall A, Eaton F, Thebaud B. Stem cell conditioned medium improves acute lung injury in mice: in vivo evidence for stem cell paracrine action. Am J Physiol Lung Cell Mol Physiol. 2012;303(11):L967-77.

75. Cruz FF, Borg ZD, Goodwin M, Sokocevic D, Wagner DE, Coffey A, Antunes M, Robinson KL, Mitsialis SA, Kourembanas S, et al. Systemic Administration of Human Bone Marrow-Derived Mesenchymal Stromal Cell Extracellular Vesicles Ameliorates Aspergillus Hyphal Extract-Induced Allergic Airway Inflammation in immunocompetent mice. Stem Cells Transl Med. 2015;4(11):1302-16.

76. Shen Q, Chen B, Xiao Z, Zhao L, Xu X, Wan X, Jin M, Dai J, Dai H. Paracrine factors from mesenchymal stem cells attenuate epithelial injury and lung fibrosis. Mol Med Rep. 2015;11(4):2831-7.

77. Timmers L, Lim SK, Hoefer IE, Arslan F, Lai RC, van Oorschot AA, Goumans MJ, Strijder C, Sze SK, Choo A, et al. Human mesenchymal stem cellconditioned medium improves cardiac function following myocardial infarction. Stem Cell Res. 2011;6(3):206-14.

78. Witwer KW, Buzas El, Bemis LT, Bora A, Lasser C, Lotvall J, Nolte-'t Hoen EN, Piper MG, Sivaraman S, Skog J, et al. Standardization of sample collection, isolation and analysis methods in extracellular vesicle research. J Extracell Vesicles. 2013;2:20360.

79. Pati S, Gerber MH, Menge TD, Wataha KA, Zhao Y, Baumgartner JA, Zhao J, Letourneau PA, Huby MP, Baer LA, et al. Bone marrow derived mesenchymal stem cells inhibit inflammation and preserve vascular endothelial integrity in the lungs after hemorrhagic shock. PLoS One. 2011; 6(9):e25171.
80. Lee JW, Fang X, Gupta N, Serikov V, Matthay MA. Allogeneic human mesenchymal stem cells for treatment of E. coli endotoxin-induced acute lung injury in the ex vivo perfused human lung. Proc Natl Acad Sci U S A. 2009;106(38):16357-62.

81. Devaney J, Horie S, Masterson C, Elliman S, Barry F, O'Brien T, Curley GF, O'Toole D, Laffey JG. Human mesenchymal stromal cells decrease the severity of acute lung injury induced by E. coli in the rat. Thorax. 2015;70(7): 625-35.

82. Hwang B, Liles WC, Waworuntu R, Mulligan MS. Pretreatment with bone marrow-derived mesenchymal stromal cell-conditioned media confers pulmonary ischemic tolerance. J Thorac Cardiovasc Surg. 2016;151(3):841-6.

83. lonescu LI, Alphonse RS, Arizmendi N, Morgan B, Abel M, Eaton F, Duszyk M, Vliagoftis H, Aprahamian TR, Walsh K, et al. Airway delivery of soluble factors from plastic-adherent bone marrow cells prevents murine asthma. Am J Respir Cell Mol Biol. 2012;46(2):207-16.

84. Hansmann G, Fernandez-Gonzalez A, Aslam M, Vitali SH, Martin T, Mitsialis SA, Kourembanas S. Mesenchymal stem cell-mediated reversal of bronchopulmonary dysplasia and associated pulmonary hypertension. Pulmonary circulation. 2012;2(2):170-81.

85. Tropea KA, Leder E, Aslam M, Lau AN, Raiser DM, Lee JH, Balasubramaniam V, Fredenburgh LE, Alex Mitsialis S, Kourembanas S, et al. Bronchioalveolar stem cells increase after mesenchymal stromal cell treatment in a mouse model of bronchopulmonary dysplasia. Am J Physiol Lung Cell Mol Physiol. 2012;302(9):L829-37.

86. Pierro M, lonescu L, Montemurro T, Vadivel A, Weissmann G, Oudit G, Emery D, Bodiga S, Eaton F, Peault B, et al. Short-term, long-term and paracrine effect of human umbilical cord-derived stem cells in lung injury prevention and repair in experimental bronchopulmonary dysplasia. Thorax. 2013;68(5): 475-84

87. Waszak P, Alphonse R, Vadivel A, lonescu L, Eaton F, Thebaud B. Preconditioning enhances the paracrine effect of mesenchymal stem cells in preventing oxygen-induced neonatal lung injury in rats. Stem Cells Dev. 2012;21(15):2789-97.

88. Wang Y, Huang L, Abdelrahim M, Cai Q, Truong A, Bick R, Poindexter B, Sheikh-Hamad D. Stanniocalcin-1 suppresses superoxide generation in macrophages through induction of mitochondrial UCP2. J Leukoc Biol. 2009;86(4):981-8.

89. Huang L, Garcia G, Lou Y, Zhou Q, Truong LD, DiMattia G, Lan XR, Lan HY, Wang $Y$, Sheikh-Hamad D. Anti-inflammatory and renal protective actions of stanniocalcin-1 in a model of anti-glomerular basement membrane glomerulonephritis. Am J Pathol. 2009;174(4):1368-78.

90. Mohammadipoor A, Lee RH, Prockop DJ, Bartosh TJ. Stanniocalcin-1 attenuates ischemic cardiac injury and response of differentiating monocytes/ macrophages to inflammatory stimuli. Transl Res. 2016;177:127-42.

91. Huh JW, Kim SY, Lee JH, Lee JS, Van Ta Q, Kim M, Oh YM, Lee YS, Lee SD. Bone marrow cells repair cigarette smoke-induced emphysema in rats. Am J Physiol Lung Cell Mol Physiol. 2011;301(3):L255-66.

92. Kim SY, Lee JH, Kim HJ, Park MK, Huh JW, Ro JY, Oh YM, Lee SD, Lee YS, Mesenchymal stem cell-conditioned media recovers lung fibroblasts from cigarette smoke-induced damage. Am J Physiol Lung Cell Mol Physiol. 2012; 302(9):L891-908.

93. Gennai S, Monsel A, Hao Q, Park J, Matthay MA, Lee JW. Microvesicles derived from human mesenchymal stem cells restore alveolar fluid clearance in human lungs rejected for transplantation. Am J Transplant Off J Am Soc Transplant Am Soc Transplant Surg. 2015;15(9):2404-12.

94. Li L, Jin S, Zhang Y. Ischemic preconditioning potentiates the protective effect of mesenchymal stem cells on endotoxin-induced acute lung injury in mice through secretion of exosome. Int J Clin Exp Med. 2015;8(3):3825-32.

95. Monsel A, Zhu YG, Gennai S, Hao Q, Hu S, Rouby JJ, Rosenzwajg M, Matthay MA, Lee JW. Therapeutic effects of human mesenchymal stem cell-derived microvesicles in severe pneumonia in mice. Am J Respir Crit Care Med. 2015;192(3):324-36.

96. Morrison TJ, Jackson MV, Cunningham EK, Kissenpfennig A, McAuley DF, O'Kane CM, Krasnodembskaya AD. Mesenchymal stromal cells modulate macrophages in clinically relevant lung injury models by extracellular vesicle mitochondrial transfer. Am J Respir Crit Care Med. 2017;196(10):1275-86.

97. Choi M, Ban T, Rhim T. Therapeutic use of stem cell transplantation for cell replacement or cytoprotective effect of microvesicle released from mesenchymal stem cell. Mol Cells. 2014;37(2):133-9.

98. Chen JY, An R, Liu ZJ, Wang JJ, Chen SZ, Hong MM, Liu JH, Xiao MY, Chen YF. Therapeutic effects of mesenchymal stem cell-derived microvesicles on 
pulmonary arterial hypertension in rats. Acta Pharmacol Sin. 2014;35(9): $1121-8$.

99. Aliotta JM, Pereira M, Wen S, Dooner MS, Del Tatto M, Papa E, Goldberg LR, Baird GL, Ventetuolo CE, Quesenberry PJ, et al. Exosomes induce and reverse monocrotaline-induced pulmonary hypertension in mice. Cardiovasc Res. 2016;1 10(3):319-30.

100. Ahn SY, Park WS, Kim YE, Sung DK, Sung SI, Ahn JY, Chang YS. Vascular endothelial growth factor mediates the therapeutic efficacy of mesenchymal stem cell-derived extracellular vesicles against neonatal hyperoxic lung injury. Exp Mol Med. 2018;50(4):26.

101. Khatri M, Richardson LA, Meulia T. Mesenchymal stem cell-derived extracellular vesicles attenuate influenza virus-induced acute lung injury in a pig model. Stem Cell Res Ther. 2018;9(1):17.

102. Kordelas L, Rebmann V, Ludwig AK, Radtke S, Ruesing J, Doeppner TR, Epple M, Horn PA, Beelen DW, Giebel B. MSC-derived exosomes: a novel tool to treat therapy-refractory graft-versus-host disease. Leukemia. 2014;28(4):970-3.

103. Nassar W, El-Ansary M, Sabry D, Mostafa MA, Fayad T, Kotb E, Temraz M, Saad AN, Essa W, Adel H. Umbilical cord mesenchymal stem cells derived extracellular vesicles can safely ameliorate the progression of chronic kidney diseases. Biomater Res. 2016;20:21.

104. Willis GR, Kourembanas S, Mitsialis SA. Toward exosome-based therapeutics: isolation, heterogeneity, and fit-for-purpose potency. Front Cardiovasc Med. 2017:4:63.

105. Exosome RNA Research and Industry News [https://www.exosome-rna.com/ aegle-therapeutics-receives-ind-clearance-from-fda-for-stem-cell-derivedextracellular-vesicle-therapy/]

106. Monsel A, Zhu YG, Gudapati V, Lim H, Lee JW. Mesenchymal stem cell derived secretome and extracellular vesicles for acute lung injury and other inflammatory lung diseases. Expert Opin Biol Ther. 2016;16(7):859-71.

107. Lee JW, Fang X, Krasnodembskaya A, Howard JP, Matthay MA. Concise review: mesenchymal stem cells for acute lung injury: role of paracrine soluble factors. Stem cells. 2011;29(6):913-9.

108. Phinney DG, Pittenger MF. Concise review: MSC-derived exosomes for cellfree therapy. Stem cells. 2017;35(4):851-8.

109. Yeo RW, Lai RC, Zhang B, Tan SS, Yin Y, Teh BJ, Lim SK. Mesenchymal stem cell: an efficient mass producer of exosomes for drug delivery. Adv Drug Deliv Rev. 2013;65(3):336-41.

110. Batrakova EV, Kim MS. Development and regulation of exosome-based therapy products. Wiley Interdiscip Rev Nanomed Nanobiotechnol. 2016; 8(5):744-57.

111. Lener T, Gimona M, Aigner L, Borger V, Buzas E, Camussi G, Chaput N, Chatterjee D, Court FA, Del Portillo HA, et al. Applying extracellular vesicles based therapeutics in clinical trials - an ISEV position paper. J Extracell Vesicles. 2015:4:30087.

112. Lorincz AM, Timar Cl, Marosvari KA, Veres DS, Otrokocsi L, Kittel A, Ligeti E. Effect of storage on physical and functional properties of extracellular vesicles derived from neutrophilic granulocytes. J Extracell Vesicles. 2014;3:25465.

113. Chen TS, Arslan F, Yin Y, Tan SS, Lai RC, Choo AB, Padmanabhan J, Lee CN, de Kleijn DP, Lim SK. Enabling a robust scalable manufacturing process for therapeutic exosomes through oncogenic immortalization of human ESCderived MSCs. J Transl Med. 2011;9:47.

114. Hu GW, Li Q, Niu X, Hu B, Liu J, Zhou SM, Guo SC, Lang HL, Zhang CQ, Wang $Y$, et al. Exosomes secreted by human-induced pluripotent stem cellderived mesenchymal stem cells attenuate limb ischemia by promoting angiogenesis in mice. Stem Cell Res Ther. 2015;6:10,

115. Stone ML, Zhao Y, Robert Smith J, Weiss ML, Kron IL, Laubach VE, Sharma AK. Mesenchymal stromal cell-derived extracellular vesicles attenuate lung ischemia-reperfusion injury and enhance reconditioning of donor lungs after circulatory death. Respir Res. 2017;18(1):212.

116. Kim YS, Kim JY, Cho R, Shin DM. Adipose stem cell-derived nanovesicles inhibit emphysema primarily via an FGF2-dependent pathway. Exp Mol Med. 2017;49(1):e284.

Ready to submit your research? Choose BMC and benefit from:

- fast, convenient online submission

- thorough peer review by experienced researchers in your field

- rapid publication on acceptance

- support for research data, including large and complex data types

- gold Open Access which fosters wider collaboration and increased citations

- maximum visibility for your research: over $100 \mathrm{M}$ website views per year

At BMC, research is always in progress.

Learn more biomedcentral.com/submissions 